\title{
Estimating Water Footprint of Different Paddy Varieties under Agroforestry
}

\author{
Subhra Suchismita Mohapatra ${ }^{1}$, M. L. Sahu ${ }^{1}$ and Yogesh Kumar ${ }^{2^{*}}$ \\ ${ }^{1}$ Department of Forestry, JNKVV, Jabalpur, India \\ ${ }^{2}$ Department of Environmental Science, Indira Gandhi National Tribal University (IGNTU), \\ Amarkantak, Madhya Pradesh, India \\ *Corresponding author
}

\section{A B S T R A C T}

\section{Keywords \\ Crop water requirement, Paddy equivalent yield, Green water footprint}

\section{Article Info}

Accepted: 12 November 2019 Available Online: 10 December 2019
The proliferation of food, feed and biofuels demands promises to increase pressure on water competition and stress, particularly for India, which has a large agricultural base. So Water Footprint (WF) has been widely spread as an indicator that contributes to a safe and sustainable use of water. The purpose of this study was to determine the WF of different paddy varieties and to search the best paddy variety which can give more yield with less water. The estimation was made using the methodology proposed in The Water Footprint Assessment Manual, according to which the WF of a crop, in this case paddy, represents the relation between the amount of water satisfying the evapotranspiration demand (CWR) and the field productivity. The WF has three components: green, associated with rain water used by the crop, blue related to underground or surface water that fulfils the evapotranspiration demand and grey, related to the volume of water required to dilute the residues of pollutants generated from the crop production. Study was carried out under eighteen year old Dalbergia sissoo based agroforestry system during the crop year of 2016-17. Three paddy varieties viz. Danteshwari (short growing period), MTU 1010 (medium growing period) and Kranti (long growing period) were selected for the study. Total water footprint of Danteshwari, MTU 1010 and Kranti were $6.214 \mathrm{~m}^{3} \mathrm{~kg}^{-1}, 3.427 \mathrm{~m}^{3}$ $\mathrm{kg}^{-1}$ and $4.455 \mathrm{~m}^{3} \mathrm{~kg}^{-1}$ respectively. Green, blue and grey water footprint of MTU 1010 was lowest among the three varieties. Green and grey water footprint of Danteshwari was highest but blue water footprint was highest in Kranti. In view of water resource conservation and yield potential MTU 1010 was found an ideal paddy variety.

\section{Introduction}

Global freshwater withdrawal has increased nearly seven-fold in the past century (Gleick, 2000). With a growing population, coupled with changing diet preferences, water withdrawals are expected to increase continuously in the coming decades (Rosegrant and Rigler, 2000). In the coming few decades, global freshwater demand will increase to meet the growing demand for food, fibre and biofuel crops (Mekonnen and 
Hoekstra, 2014). The growing world population requires increased food production, while less water resources are available for agriculture. This alarming situation can only be resolved if water is managed more efficiently, so that crop yield per unit of water consumption increases (World Bank, 2003). In the agricultural sector one of the most water intensive crop is rice. The increasing demand for rice in combination with increasing water scarcity is a threat for food security and the sustainability of rice cultivation. The impact of rice consumption on global water resources can be mapped with the water footprint, a concept introduced by Hoekstra in 2002. This water footprint is defined as 'the total volume of fresh water that is used to produce the foods'. Using this consumption based indicator as a tool to provide information on water use related to the consumption of products could be useful (Mom, 2007). The water footprint is a geographically explicit indicator, not only showing volumes of water use and pollution, but also the locations. Water Footprint is composed of three parts green (rainwater), blue (irrigation water) and grey waters (volume of fresh water that is required to assimilate the load of pollutants) (Lovarelli et al., 2016). The total water footprint of crop (WF) is the sum of the green, blue and grey water components (Mizutani, 2010). The water footprint thus offers a better and wider perspective on water management. It is a volumetric measure of water consumption and pollution. The water footprint is always expressed as water volume per unit of product $\left(\mathrm{m}^{3} \mathrm{~kg}^{-1}\right)$ (Hoekstra et al., 2011). Soil physical and plant biophysical knowledge can be used to develop practices to maximize the utility of green water, minimizing blue water and grey water (Clothier, 2010). Agroforestry offers promising option for efficient and sustainable use of land and water. Water conservation and more productive use of water is one of the key benefits of agroforestry. Agroforestry can improve soil fertility, provide fodder, produce tree fruits, expand fuel wood supplies and produce a variety of wood products for farmer's own use and sale without demanding additional land (Kumar, 2016). In addition to providing natural resources, agroforestry systems have the potential to maintain higher levels of biodiversity and greater biomass than monocrop or pasture system (Seeta et al., 2016). Considering the above facts the present study has been planned. The objective of the study was to evaluate the water footprint of different paddy varieties under agroforestry.

\section{Materials and Methods}

The field experiment was conducted during the crop year 2016-17 at Dusty Acre Research Farm, Department of Forestry, Jawaharlal Nehru Krishi Vishwa Vidyalaya, Jabalpur (M.P.). The study area enjoys a subtropical climate with hot dry summer and cool dry winter. Average annual rainfall of the area is $1350 \mathrm{~mm}$. The topography of the area is plain to gently sloping. Slope of the land vary from 0 to $1 \%$. Soil is clay loam. Three paddy varieties were grown under eighteen year old Dalbergia sissoo (Roxb.) plantation. These trees were planted in July 1998 with planting geometry of $5 \mathrm{~m}$ x $5 \mathrm{~m}$. Paddy varieties were Danteshwari (matures in 90-95 days), MTU 1010 (matures in 100-110 days) and Kranti (matures in 120-135 days). Dates of sowing were $4^{\text {th }}$ July $2016,5^{\text {th }}$ July 2016 and $7^{\text {th }}$ July 2016 respectively for Danteshwari, MTU 1010 and Kranti. Respective dates of harvesting were $7^{\text {th }}$ October 2016, $18^{\text {th }}$ October 2016 and $9^{\text {th }}$ November 2016. Outputs are paddy grain and Paddy straw. To derive the water footprint daily rain fall $(\mathrm{mm})$, daily maximum and minimum temperature $\left({ }^{\circ} \mathrm{C}\right)$, average of daily morning and evening relative humidity (\%), daily wind speed $\left(\mathrm{km}\right.$ day $\left.{ }^{-1}\right)$ and daily sun shine hours were considered. The daily rainfall was converted in to effective rainfall $\left(\mathrm{R}_{\mathrm{eff}}\right)$ by using fixed percentage of daily rain 
fall data as suggested in CROPWAT 8.0 model. All the weather parameters were used to get the Reference Evapotranspiration $\left(\mathrm{ET}_{\mathrm{O}}\right)$ in the Penman-Monteith Method on CROPWAT 8.0. Green and blue water Evapotranspiration during the crop growth was estimated with crop water requirement (CWR). The crop water requirement is the water needed for evapotranspiration under ideal growth conditions, measured from planting to harvest. 'Ideal conditions' means that adequate soil water is maintained by rainfall and/or irrigation so that it does not limit plant growth and crop yield. Crop water requirement was calculated by multiplying the reference crop Evapotranspiration (ETo) to the crop coefficient $(\mathrm{Kc}): \mathrm{CWR}=\mathrm{Kc} \times$ ETo. It was assumed that the crop water requirements were fully met, so that actual crop evapotranspiration (ETc) will be equal to the crop water requirement: ETc $=\mathrm{CWR}$. The crop coefficient $(\mathrm{Kc})$ varied over the length of the growing period. Values for Kc for crops over the length of the growing period were taken from the literature (FAO. Irrigation and drainage paper no.56) which is based on the crop growth stages of 10 days interval period.

The irrigation requirement (IR) was calculated as the difference between crop water requirement and effective rainfall $\left(\mathrm{R}_{\mathrm{eff}}\right)$. The irrigation requirement was zero if effective rainfall was larger than the crop water requirement. This means: IR $=\max (0, \mathrm{CWR}$ - $\mathrm{R}_{\mathrm{eff}}$ ). It was assumed that the irrigation requirements were fully met. Green water evapotranspiration ( $\left.\mathrm{ET}_{\text {green }}\right)$, in other words, evapotranspiration of rainfall, could be equated with the minimum of total crop evapotranspiration $\left(\mathrm{ET}_{\mathrm{c}}\right)$ and effective rainfall. Blue water evapotranspiration $\left(\mathrm{ET}_{\text {blue }}\right)$, in other words, field-evapotranspiration of irrigation water, was equal to the total crop evapotranspiration minus effective rainfall, but zero when effective rainfall exceeds crop evapotranspiration:
$\mathrm{ET}_{\text {green }}=\min \left(\mathrm{ET}_{\mathrm{c}}, \mathrm{R}_{\mathrm{eff}}\right)[$ length/time $]$

$\mathrm{ET}_{\text {blue }}=\max \left(0, \mathrm{ET}_{\mathrm{c}}-\mathrm{R}_{\text {eff }}\right)[$ length/time $]$

All water flows were expressed in $\mathrm{mm} \mathrm{day}^{-1}$ or in mm per period of simulation (e.g. ten days). The green and blue components in crop water use (CWU, $\mathrm{m}^{3} \mathrm{ha}^{-1}$ ) were calculated by accumulation of daily evapotranspiration (ET, $\mathrm{mm}$ day $^{-1}$ ) over the complete length of growing period (lgp):

$$
\begin{aligned}
& \operatorname{lgp}_{\mathrm{CWreen}}=10 \times \Sigma \mathrm{ET}_{\text {green }} \\
& \mathrm{d}=1 \\
& \operatorname{lgW}_{\text {blue }}=10 \times \Sigma \mathrm{ET}_{\text {blue }} \\
& \mathrm{d}=1
\end{aligned}
$$

The green water footprint of crop $\left(\mathrm{WF}_{\text {green }}, \mathrm{m}^{3}\right.$ $\mathrm{kg}^{-1}$ ) was calculated as the green component in crop water use $\left(\mathrm{CWU}_{\text {green }}, \mathrm{m}^{3} \mathrm{ha}^{-1}\right)$ divided by the crop yield $\left(\mathrm{Y}, \mathrm{kg} \mathrm{ha}^{-1}\right)$.

$\mathrm{WF}_{\text {green }}=\mathrm{CWU}_{\text {green }} / \mathrm{Y}($ Volume $/$ mass $)$

The blue water footprint of crop $\left(\mathrm{WF}_{\text {blue }}, \mathrm{m}^{3}\right.$ $\mathrm{kg}^{-1}$ ) was calculated as the blue component in crop water use $\left(\mathrm{CWU}_{\text {blue }}, \mathrm{m}^{3} \mathrm{ha}^{-1}\right)$ divided by the crop yield (Y, $\left.\mathrm{kg} \mathrm{ha}^{-1}\right)$.

$\mathrm{WF}_{\text {blue }}=\mathrm{CWU}_{\text {blue }} / \mathrm{Y}($ Volume $/$ mass $)$

The grey component in the water footprint of crop $\left(\mathrm{WF}_{\text {grey }}, \mathrm{m}^{3} \mathrm{~kg}^{-1}\right.$ ) was calculated as the chemical application rate to the field per hectareAR, $\left(\mathrm{kg} \mathrm{ha}^{-1}\right)$ times the leaching-runoff fraction $(\alpha)$ divided by the maximum acceptable concentration $\left(\mathrm{C}_{\max }, \mathrm{kg} \mathrm{m}^{-3}\right)$ minus the natural concentration for the pollutant considered $\left(\mathrm{C}_{\text {nat }}, \mathrm{kg} \mathrm{m}^{-3}\right)$ and then divided by the crop yield ( $\left.\mathrm{Y}, \mathrm{kg} \mathrm{ha}^{-1}\right)$.

$\mathrm{WF}_{\text {grey }}=\left(\begin{array}{lllllll}\alpha & \times & \mathrm{AR} & / & \mathrm{C}_{\max } & -\mathrm{C}_{\text {nat }}\end{array}\right) / \mathrm{Y}$ (Volume/mass) 
The pollutant generally considered here for crop were nitrogen, phosphorus and metal (Zinc). Potassium was not considered here, as it is totally absorbed by the crop.

All the values for leaching runoff fraction, maximum concentration and natural concentration for nitrogen, phosphorous and metal were taken from the literature Grey water footprint accounting, Tire 1 supporting guidelines (Franke et al., 2013).

All the values of maximum and natural concentration were converted in to $\mathrm{kg} \mathrm{m}^{-3}$. Rate of application of fertilizer was 100:60:40:: N: P: K $\left(\mathrm{Kg} \mathrm{ha}^{-1}\right)$. Total water footprint was calculated by summing all three components

$\mathrm{WF}_{\text {total }}=\mathrm{WF}_{\text {green }}+\mathrm{WF}_{\text {blue }}+\mathrm{WF}_{\text {grey }}($ Volume /mass)

Analysis of data was carried out in strip plot design having four main treatments (pruning), three sub treatments (paddy variety) and five replications.

\section{Results and Discussion}

\section{Paddy grain yield of different varieties}

Among three paddy varieties grain yield of MTU $1010\left(1350 \mathrm{~kg} \mathrm{ha}^{-1}\right)$ was at par with Kranti (1229 $\mathrm{kg} \mathrm{ha}^{-1}$ ) but significantly superior to Danteshwari $\left(852 \mathrm{~kg} \mathrm{ha}^{-1}\right)$. Yield of Danteshwari was significantly lower to Kranti (Table 1).

\section{Paddy straw yield of different varieties}

Trend of straw yield was similar to grain yield. Straw yield of MTU $1010\left(2120 \mathrm{~kg} \mathrm{ha}{ }^{-}\right.$ $\left.{ }^{1}\right)$ was at par with Kranti $\left(2150 \mathrm{~kg} \mathrm{ha}^{-1}\right)$ but significantly superior to Danteshwari $(1235 \mathrm{~kg}$ $\mathrm{ha}^{-1}$ ). The straw yield was converted into Paddy Equivalent Yield (PEY) (Table 1).
Paddy Equivalent Yield (PEY) of grain and straw

Paddy Equivalent Yield (grain + straw) of MTU 1010 (1974 $\left.\mathrm{kg} \mathrm{ha}^{-1}\right)$ was significantly superior to Danteshwari $\left(1215 \mathrm{~kg} \mathrm{ha}^{-1}\right)$ but at par with Kranti $\left(1861 \mathrm{~kg} \mathrm{ha}^{-1}\right)$. PEY of Kranti was superior to Danteshwari (Table 1).

Green, blue, grey and total water use by the crop

Green water use of different paddy varieties during kharif season was found to be maximum for Danteshwari $\left(2903 \mathrm{~m}^{3} \mathrm{ha}^{-1}\right)$ followed byMTU $1010\left(2834 \mathrm{~m}^{3} \mathrm{ha}^{-1}\right)$ and Kranti $\left(2723 \mathrm{~m}^{3} \mathrm{ha}^{-1}\right)$. Statistically green water uses of all three varieties were at par (Table 2).

The trend of blue water use of different paddy varieties was just reverse to green water use and found to be maximum for Kranti $\left(1499 \mathrm{~m}^{3}\right.$ $\left.\mathrm{ha}^{-1}\right)$ followed byMTU $1010\left(1017 \mathrm{~m}^{3} \mathrm{ha}^{-1}\right)$ and Danteshwari $\left(719 \mathrm{~m}^{3} \mathrm{ha}^{-1}\right)$. Statistically blue water use is also at par in all variety (Table 2).

Grey water use for all the paddy varieties was same due to recommended dose of fertilizer for the all experimental plots. It was found to be $2694 \mathrm{~m}^{3} \mathrm{ha}^{-1}$ (Table 2).

Total water use of all three paddy varieties were at par. Numeric values are $6316 \mathrm{~m}^{3} \mathrm{ha}^{-1}$, $6545 \mathrm{~m}^{3} \mathrm{ha}^{-1}$ and $6916 \mathrm{~m}^{3} \mathrm{ha}^{-1}$ respectively for Danteshwari, MTU 1010 and Kranti (Table 2).

\section{Water footprint (WF)}

Paddy is one of the water intensive crop so it is desirable that total water footprint of paddy should be as low as possible in agroforestry systems. Green, blue and grey water footprints are the three components of total water footprint. With the condition of lower total 
water footprint it is desirable that each component viz. green, blue and grey water footprint should also be as low as possible.

\section{Green water footprint of paddy $\left(\mathrm{WF}_{\text {green }}\right)$}

Green WF of MTU $1010\left(1.484 \mathrm{~m}^{3} \mathrm{~kg}^{-1}\right)$ and Kranti $\left(1.754 \mathrm{~m}^{3} \mathrm{~kg}^{-1}\right)$ are at par but significantly lower than Danteshwari (2.856 $\mathrm{m}^{3} \mathrm{~kg}^{-1}$ ) (Table 3). It means MTU 1010 used only 1484 liters of rainfall to produce $1 \mathrm{~kg}$ PEY as compare to Kranti (1754 litres) and Danteshwari (2856 liters).

Danteshwari variety may be promoted in the area where rainfall is higher and it is going waste in the form of runoff. By utilizing most of the rains Danteshwari may reduce the flood peaks and downstream runoff. MTU 1010 and Kranti are suitable for low rainfall area in view of efficient water management strategy.

One of the effective way to reduce the green water footprint is to use direct dry seeding method which will increase the effective use of rainfall and reduce irrigation needs (Cabangon et al., 2002).

\section{Blue water footprint of paddy $\left(\mathrm{WF}_{\text {blue }}\right)$}

Blue WF of MTU $1010\left(0.532 \mathrm{~m}^{3} \mathrm{~kg}^{-1}\right)$ was significantly lowest among the three paddy varieties. Blue WF of Danteshwari $\left(0.707 \mathrm{~m}^{3}\right.$ $\left.\mathrm{kg}^{-1}\right)$ was higher than MTU 1010 but significantly lower than Kranti $\left(0.965 \mathrm{~m}^{3}\right.$ $\mathrm{kg}^{-1}$ ) (Table 3). Irrigation requirement of MTU 1010 was lowest among the three varieties. It used only 532 liters irrigation water to produce $1 \mathrm{~kg}$ of $\mathrm{PEY}$ as compare to Danteshwari (707 liters)and Kranti (965 liters).

Reduced irrigation requirement is desired very much as it lower downs the cost of cultivation. From an economic point of view, reducing percolation of blue water in the rice fields is relevant, because it will reduce costs of water supply by reducing the absolute volume of water needed in the field (Chapagain and Hoekstra, 2011).

\section{Grey water footprint of paddy $\left(\mathrm{WF}_{\text {grey }}\right)$}

Grey WF of MTU $1010\left(1.411 \mathrm{~m}^{3} \mathrm{~kg}^{-1}\right)$ and Kranti $\left(1.735 \mathrm{~m}^{3} \mathrm{~kg}^{-1}\right)$ were at par but significantly lower than Danteshwari (2.650 $\mathrm{m}^{3} \mathrm{~kg}^{-1}$ ) (Table 3). It means MTU 1010 used only 1411 liters per $\mathrm{kg}$ of water to nullify the residual effect of fertilizer and metals applied to the crop as compare to Kranti (1735 liters per $\mathrm{kg}$ ) and Danteswari (2650 liters per kg). The grey component of the water footprint can only be lower down by reducing the leaching of fertilizers and pesticides from the field. The loss of nitrogen may cause environmental and health problems (Choudhury and Kennedy, 2005).

\section{Total water footprint of paddy $\left(\mathrm{WF}_{\text {total }}\right)$}

The trend of total water footprint was exactly similar to grey water footprint. Total water footprint of MTU $1010\left(3.427 \mathrm{~m}^{3} \mathrm{~kg}^{-1}\right)$ and Kranti $\left(4.455 \mathrm{~m}^{3} \mathrm{~kg}^{-1}\right)$ were at par but significantly lower than Danteshwari (6.214 $\mathrm{m}^{3} \mathrm{~kg}^{-1}$ ) (Table 3). It means total water used to produce $1 \mathrm{~kg}$ of PEY is only 3427 liters for MTU 1010 as compare to 4455 liters and 6214 liters respectively for Kranti and Danteshwari. Total water footprint is the sum of Green water footprint, Blue water footprint and Grey water footprint.

$\left(\mathrm{WF}_{\text {total }}\right)=\left(\mathrm{WF}_{\text {green }}\right)+\left(\mathrm{WF}_{\text {blue }}\right)+\left(\mathrm{WF}_{\text {grey }}\right)$

Among three selected paddy variety the total water footprint of MTU 1010 was lowest. Total WF of Kranti was minutely higher but at par with MTU 1010. Total WF of Danteshwari was highest. Danteshwari may be suitable for high rainfall areas, as it utilizes more rainfall which ultimately reduces runoff load and peak floods in downstream. 
Table.1 Paddy Equivalent Yield (PEY) of different varieties

\begin{tabular}{|c|c|c|c|}
\hline Paddy Variety & $\begin{array}{c}\text { Grain Yield } \\
\text { Kg ha }^{-\mathbf{1}}\end{array}$ & $\begin{array}{c}\text { Straw Yield } \\
\text { Kg ha }^{-\mathbf{1}}\end{array}$ & $\begin{array}{c}\text { PEY (grain+straw) } \\
\text { Kg ha }^{-\mathbf{1}}\end{array}$ \\
\hline Danteshwari & 852 & 1235 & 1215 \\
\hline MTU 1010 & 1350 & 2120 & 1974 \\
\hline Kranti & 1229 & 2150 & 1861 \\
\hline SEm \pm & 67 & 101 & 96 \\
\hline CD $(\mathbf{p}=\mathbf{0 . 0 5})$ & 217 & 330 & 313 \\
\hline
\end{tabular}

Table.2 Green, Blue, Grey and total water use by the crop

\begin{tabular}{|c|c|c|c|c|}
\hline Paddy Variety & $\begin{array}{c}\text { Green water } \\
\mathbf{m}^{\mathbf{3}} \mathbf{h a}^{-\mathbf{1}}\end{array}$ & $\begin{array}{c}\text { Blue water } \\
\mathbf{m}^{\mathbf{3}} \mathbf{h a}^{-\mathbf{1}}\end{array}$ & $\begin{array}{c}\text { Grey water } \\
\mathbf{m}^{\mathbf{3}} \mathbf{h a}^{\mathbf{- 1}}\end{array}$ & $\begin{array}{c}\text { Total water } \\
\mathbf{m}^{\mathbf{3}} \mathbf{h a}^{\mathbf{- 1}}\end{array}$ \\
\hline Danteshwari & 2903 & 719 & 2694 & 6316 \\
\hline MTU 1010 & 2834 & 1017 & 2694 & 6545 \\
\hline Kranti & 2723 & 1499 & 2694 & 6916 \\
\hline SEm \pm & NS & NS & NS & NS \\
\hline CD $(\mathbf{p = 0 . 0 5 )}$ & NS & NS & NS & NS \\
\hline
\end{tabular}

Table.3 Green, Blue, Grey and total water footprint of different paddy varieties

\begin{tabular}{|c|c|c|c|c|}
\hline $\begin{array}{l}\text { Paddy } \\
\text { Variety }\end{array}$ & $\begin{array}{c}\text { Green WF } \\
\mathbf{m}^{3} \mathbf{k g}^{-1}\end{array}$ & $\begin{array}{c}\text { Blue WF } \\
\text { m }^{3} \mathbf{k g}^{-1}\end{array}$ & $\begin{array}{c}\text { Grey WF } \\
\text { m }^{3} \mathbf{k g}^{-1}\end{array}$ & $\begin{array}{c}\text { Total WF } \\
\mathbf{m}^{3} \mathrm{~kg}^{-1}\end{array}$ \\
\hline Danteshwari & 2.856 & 0.707 & 2.650 & 6.214 \\
\hline MTU 1010 & 1.484 & 0.532 & 1.411 & 3.427 \\
\hline Kranti & 1.754 & 0.965 & 1.735 & 4.455 \\
\hline SEm \pm & 0.198 & 0.049 & 0.183 & 0.425 \\
\hline $\mathrm{CD}(\mathrm{p}=\mathbf{0 . 0 5})$ & 0.647 & 0.160 & 0.597 & 1.385 \\
\hline
\end{tabular}

Total WF of MTU 1010 and Kranti are at par hence suitable for low rainfall areas. Among MTU 1010 and Kranti, MTU 1010 is better because its irrigation requirement is less and biomass production is higher than Kranti. Growing period of MTU 1010 is also shorter than Kranti. Hence in view of water resource conservation and yield potential MTU 1010 is an ideal paddy variety.

\section{Acknowledgement}

Investigator of All India Coordinated Research Project on Agroforestry, Head Department of Forestry, Director Research Services and Hon' ble Vice -Chancellor of Jawaharlal Nehru Krishi Vishwa Vidyalaya, Jabalpur, MP. They are also indebted to Project Coordinator and Nodal officer AICRP on AF Jhansi, for providing all facilities and fund to conduct the experiment.

\section{References}

Allen, R.G., Pereira, L.S., Raes, D. and Smith, M. 2006. Crop evapotranspiration: Guidelines for computing crop water requirements. FAO Irrigation and Drainage paper 56, Food and Agriculture Organization, Rome.

Anonymous World Bank.2003. Crop and Water Productivity of the Pakistan Wheat and Rice Systems. General Foulkesweg 286703 BS Wageningen, the Netherlands. www.WaterWatch.nl. 
Cabangon, R.J., Tuong, T.P. and Abdullah, N.B. 2002. Comparing water input and water productivity of transplanted and directseeded rice production systems. Agricultural Water Management 57 (1), $11-13$.

Chapagain, A.K. and Horkstra, A.Y. 2011. The blue, green and grey water footprint of rice from production and consumption perspectives. Ecological Economics 70:749-758.

Choudhury, A.T.M.A. and Kennedy, I.R. 2005. Nitrogen fertilizer losses from rice soil and control of environmental pollution problems. Communications in Soil Sciences and Plant Analysis 36, 16251639.

Clothier, B., Green, S. and Deurer, M. 2010. Green, Blue and Grey Waters: Minimizing the footprint using soil physics. $19^{\text {th }}$ world congress of soil science, Soil solution for a changing world, 1-6 August, Brisbane, Australia, pp 81-84.

FAO. 2010b. CROPWAT 8.0 model.FAO, Rome, www.fao.org/nr/water/infores database_cropwat.html.

Franke, N.A., Boyacioglu, H. and Hoekstra, A.Y. 2013. Grey water footprint accounting. Tire 1 supporting guidelines, Value of Water Research Report Series No. 65, UNESCO-IHE, Delft, the Netherlands.pp 7-57.

Gleick, P.H. 2000. The changing water paradigm: a look at twenty-first century water resources development, Water International 25(1):127-138

Hoekstra, A.Y., Chapagain, A.K., Aldaya, M.M. and Mekonnen, M.M. 2011. The Water Footprint Assessment Manual, Setting the Global Standrad. pp 3-142.

Kumar, V. 2016. Multifunctional agroforestry systems in tropics region. Nature Environment and Pollution Technology an International Quarterly Scientific Journal 15(2): 365-376.

Lovarelli, D., Bacenetti, J. and Fiala, M. 2016. Water Footprint of crop productions: A review. Science of the total environment 548-549,pp 236-251.

Maclean, J.L., Dawe, D.C., Hardy, B. and Hettel, G.P. (Eds.). 2002. Rice almanac International Rice Research Institute, The Philippines.

Mekonnen, M.M. and Hoekstra, A.Y. 2014. Water footprint benchmarks for crop production: A first global assessment. Ecological indicators $46: 214-223$.

Mizutani, Y. 2010. Water footprint. Consultative Meeting on Water \& Wastewater Management, Global Environment Centre Foundation OSAKA, JAPAN.

Mom, R. 2007. A high spatial resolution analysis of the water footprint of global rice consumption. Master Thesis, University of Twente, Enschede, The Netherlands. pp 1-2.

Rosegrant, M.W. and Ringler, C. 2000. Impact on food security and rural development of transferring water out of agriculture, Water Policy 1(6): 567-586.

Seeta, A., Sistla, Adam B., Roddy, Nicholas E., Williams, Daniel B.K., Stevens, K. and Steven, D.A. 2016. Agroforestry practices promote biodiversity and natural resource diversity in Atlantic Nicaragua.PLoS One Publication 11(9): 1-20.

Smith, B.D. 1998. The emergence of agriculture. Scientific American Library, A Division of HPHLP, New York.

Zeigler, R.S. and Barclay, A. 2008. The relevance of rice. Rice 1 (1), 3-10.

\section{How to cite this article:}

Subhra Suchismita Mohapatra, M. L. Sahu and Yogesh Kumar. 2019. Estimating Water Footprint of Different Paddy Varieties under Agroforestry. Int.J.Curr.Microbiol.App.Sci. 8(12): 1609-1615. doi: https://doi.org/10.20546/ijcmas.2019.812.193 